\title{
THE ROLE OF THE ENDOPARASITOIDS Opius pallipes WESMEAL (HYMENOPTERA: BRACONIDAE) AND Chrysocharis parksi CRAWFORD (HYMENOPTERA: EULOPHIDAE) AS BIOAGENTS AGAINST THE SERPENTINE LEAFMINER, Liriomyza trifolii (BURGESS) IN TOMATO GREENHOUSES . \\ Kassem, S. A. A. \\ Sakha Agric.Res. Station, Plant Protection Res. Inst., Agric. Res. Center.
}

\begin{abstract}
Natural abundance of the endoparasitoids Opius pallipes Wesmeal and Chrysocharis parksi Crawford was studied in four tomato greenhouses at Sakha Agricultural Research Station. The greenhouses were planted with the tomato varieties, Hybrid G512 (Greenhouse 1), Hybrid TY 70/84 (Greenhouse 2), TY 70/70 (Greenhouse 3) and TY 71 (Greenhouse 4). The parasitoids showed high populations in April and May which kept the populations of the serpentine leafminer Liriomyza trifolii (Burgess) at low densities till the end of the season in all studied greenhouses.

$O$. pallipes recorded two peaks of abundance in all greenhouses, the highest peak recorded $7,5,7$ and 7 individuals $/ 50$ infested leaflets in greenhouses 1, 2, 3 and 4 respectively, while the highest average numbers occurred in April in all greenhouses recording $4.5 \pm 2.1,3.1 \pm 1.6,4.5 \pm 2.2$ and $4.5 \pm 2.1$ individuals/50 infested leaflets in greenhouses $1,2,3$ and 4 respectively. The percentages of parasitism reached $30.4 \%, 38.5 \%, 31.6 \%$ and $30.4 \%$ in greenhouses $1,2,3$ and 4 respectively.

C. parksi recorded two peaks of abundance in all greenhouses. The highest peak recorded 8, 7, 7 and 6 individuals/50infested leaflets in greenhouses 1,2,3 and 4 respectively, while the highest average numbers occurred in April in greenhouses 1and 4 recording $5.3 \pm 2.1$ and $5.2 \pm 2.2$ individuals/50infested leaflets respectively and in march in greenhouses 2and 3 recording $4.1 \pm 1.4$ and $4.0 \pm 1.4$ individuals/50 infested leaflets respectively, while percentages of parasitism reached $38.1 \%, 36.8$ $\%, 27.7 \%$ and $38.1 \%$ in greenhouses $1,2,3$ and 4 respectively.
\end{abstract}

\section{INTRODUCTION}

The most dominant endoparasitoid species against Liriomyza trifolii of the parasitoid complex are O.pallipes Wesmeal and Chrysocharis parksi (ElKhouly, 2003). McClanahan (1975) found that Opius spp.are the most abundant parasitoid species on tomatoes infested with Liriomyza sativa, and L. trifolii. Linden (1986) evaluated the combination of two European parasitoids; O.pallipes, D. isaea and two American ones; C. parksi and Opoius dimidiatus in biological control of the agromyzid leaf miners, L. trifolii and L. bryonia in Dutch greenhouses. He found that the tomato leaf miner Liriomyza bryonia occurred from June on words, but without a problem because of the high rate of parasitism of spontaneously occurring Dacnusa sibirica and $O$. pallipes, while $C$. parksi reached $45 \%$. He also concluded that the exotic leaf miner parasitoids; $C$. parksi and $O$. dimidiatus survive in Dutch glasshouses and sometimes may have a considerable contribution to the biological control of Liriomyza spp., together with native parasitic species. 
Shahein and El-Magraby (1993) concluded that the percentage of parasitism on L.trifolii was initially low and reached its maximum in midMarch. The percentage of parasitism by the braconid Opius sp. was $20.8 \%$ of the total parasitism. Ckman and Uygun (2003) studied the parasitoid complex of the agromyzid leaf miners in the Turkish fauna. They identified six parasitoids from Braconidae and 12 from Eulophidae. Among the parasitoids, Opius spp. and Chrysocharis spp. were the most dominant parasitoids. Johnson et al. (1980) observed that $C$. parksi is a very abundant parasitoid in California in outdoors and glasshouses, and has shown to influence the leaf miner populations in tomatoes significantly. Parrella (1984) sent a shipment of the parasitoid C. parksi from USA to Netherlands to control leaf miners. The reasons for him to use this parasite were a) Mass-rearing is possible b) It is a larval pupal parasitoid c) High fecundity d) Development time is short and e) it is compatible with low rates of insect growth regulation. Lyon (1986) reported that indigenous parasites especially $C$. parksi were introduced at the beginning of each culture to control L.trifolii in tomato greenhouses in combination with the eulophid $D$. isaea. Moreover, C. parksi was shown to be the predominant parasite on tomatoes in California when L. sativa was a predominant leaf miner species (Zehnder and Trumble, 1984). The parasitoid C. parksi played an important role as biocontrol agent on L. trifolii in tomato fields but showed less preference towards tomatoes in comparison with cowpea or kidney bean (El-Khouly, 2009).

From the available literature, few authors have studied the role of the parasitoids, C. parksi and $O$. pallipes as biocontrol agents against $L$. trifolii in tomato fields in the Egyptian fauna, but rarely in tomato greenhouses. Therefore, the present investigation was undertaken to study the role of the endoparasitoids; C. parksi and O. pallipes in tomato greenhouses.

\section{MATERIALS AND METHODS}

The present study was carried out at Sakha Agricultural Research Station, Kafr El-Sheikh governorate from March to June 2009. Four.The greenhouses 1, 2, 3 and 4 (500 $\mathrm{m}^{2}$ each) were planted with 30 days tomato nursling old. The greenhouses $1,2,3$ and 4 were planted with tomato cultivars, Hybrid G512, Hybrid TY70/84, Hybrid TY70/70 and TY71, respectively .Normal cultural practices were followed inside the greenhouses, but without any pesticides. Fifty tomato leaflets infested with $L$. trifolii were taken from each greenhouse seven days after planting till harvest. Samples were kept in plastic bags and transferred to be examined in the laboratory. The collected living larvae of $L$. trifolii of each sample were kept under laboratory conditions in Petri dishes till the emergence of the pest or its parasitoids, O. pallipes or C. parksi. Filter papers used in Petri dishes were remoistened when necessary to avoid drying. The number of parasitoids were counted and recorded.

\section{RESULTS}

Data illustrated in Fig (1) show the numbers of the endoparasitoids $O$. pallipes, and $C$. parksi in four tomato greenhouses .

In greenhouse (1), the parasitoid $O$. pallipes recorded two peaks of abundance ( 7 and 6 individuals $/ 50$ infested leaflets) on $20^{\text {th }}$ of April and $25^{\text {th }}$ 
of May, respectively. On the other hand, the parasitoid $C$. parksi recorded two peaks of abundance ( 8 and 8 individuals/50 infested leaflets) on $13^{\text {th }}$ of April and $25^{\text {th }}$ of May, respectively.

In greenhouse (2), the parasitoid $O$. pallipes recorded two peaks of abundance (5 and 5 individuals/50infested leaflets) on $13^{\text {th }}$ of April and $1^{\text {st }}$ of June respectively. The parasitoid $C$. parksi recorded two peaks of abundance (5and 7 individuals/50infested leaflets) on $30^{\text {th }}$ of March and $13^{\text {th }}$ of April, respectively.

In greenhouse (3), the parasitoid $O$. pallipes recorded two peaks of abundance ( 7 and 6 individuals/50infested leaflets) on $13^{\text {th }}$ of April and $18^{\text {th }}$ of May, respectively. On the other hand, the parasitoid $C$. parksi recorded two peaks of abundance ( 6 and 5 individuals/50 infested leaflets) on $13^{\text {th }}$ of April and $18^{\text {th }}$ of May, respectively.

In greenhouse (4), the parasitoid $O$. pallipes recorded two peaks of abundance ( 7 and 6 individuals $/ 50$ infested leaflets) on $20^{\text {th }}$ of April and $25^{\text {th }}$ of May, respectively. On the other hand the parasitoid C. parksi recorded two peaks of abundance ( 8 and 8 individuals $/ 50$ infested leaflets) on $13^{\text {th }}$ of April and $25^{\text {th }}$ of May, respectively.

As shown in Table (1), the parasitoid $O$. pallipes showed its highest monthly average numbers in April in the four greenhouses recording $4.5 \pm$ $2.1,3.1 \pm 1.6,4.5 \pm 2.2$ and $4.5 \pm 2.1$ individuals/50 infested leaflets) in greenhouses 1, 2, 3 and 4, respectively. On the other hand the parasitoid $C$. parksi showed its highest monthly average numbers in April in greenhouses 1and 4, recording $5.3 \pm 2.1$ and $5.2 \pm 2.2$ individuals/50 infested leaflets respectively and in March in greenhouses 2 and 3 recording $4.1 \pm 1.4$ and 4.0 \pm 1.4 individuals $/ 50$ infested leaflets, respectively.

Data illustrated in Fig (2) show the percentages of parasitism by the endoparasitoids $O$. pallipes and $C$. parksi in four tomato greenhouses .

In greenhouse (1), the percentage of parasitism by the endoparasitoids O. pallipes ranged $0.0-30.4 \%$ and recorded its peak in $20^{\text {th }}$ of April. On the other hand, the percentages of parasitism by the endoparasitoid C. parksi ranged $0.0-38.1 \%$ and recorded its peak on $13^{\text {th }}$ of April .

In greenhouse (2), the percentage of parasitism by the endoparasitoids O. pallipes ranged $0.0-38.5 \%$ and recorded its peak on $1^{\text {st }}$ of June. On the other hand, the percentages of parasitism by the endoparasitoid C. parksi ranged $0.0-36.8 \%$ and recorded its peak on $13^{\text {th }}$ of April .

In greenhouse (3), the percentage of parasitism by the endoparasitoids O. pallipes ranged $0.0-31.6 \%$ and recorded its peak on $6^{\text {th }}$ of April. On the other hand, the percentages of parasitism by the endoparasitoid C. parksi ranged $0.0-27.7 \%$ and recorded its peak on $30^{\text {th }}$ of March .

Table (1): Monthly average numbers of the endoprasitoids $O$. pallipes and $C$. parksi in four tomato cultivars.

\begin{tabular}{|l|c|c|c|c|c|c|c|c|}
\hline \multirow{2}{*}{ Month } & \multicolumn{2}{|c|}{ Hybrid G12 } & \multicolumn{2}{c|}{ Hybrid TY 70/84 } & \multicolumn{2}{c|}{ Hybrid TY 70/70 } & \multicolumn{2}{c|}{ Hybrid TY 71 } \\
\cline { 2 - 9 } & O. pallipes & C. parksi & O. pallipes & C. parksi & O. pallipes & C. parksi & O. pallipes & C. parksi \\
\hline March & $2.5 \pm 0.7$ & $3.5 \pm 0.7$ & $3.0 \pm 1.4$ & $4.1 \pm 1.4$ & $3.5 \pm 2.1$ & $4.0 \pm 1.4$ & $2.5 \pm 0.7$ & $3.5 \pm 0.7$ \\
\hline April & $4.5 \pm 2.1$ & $5.3 \pm 2.1$ & $3.1 \pm 1.6$ & $3.5 \pm 2.6$ & $4.5 \pm 2.2$ & $3.8 \pm 1.7$ & $4.5 \pm 2.1$ & $5.2 \pm 2.2$ \\
\hline May & $2.2 \pm 2.6$ & $2.8 \pm 3.6$ & $1.0 \pm 1.2$ & $1.0 \pm 1.4$ & $2.5 \pm 2.4$ & $2.5 \pm 1.9$ & $2.2 \pm 2.6$ & $2.8 \pm 3.6$ \\
\hline June & $1.3 \pm 1.5$ & $1.6 \pm 1.2$ & $2.0 \pm 2.6$ & $1.7 \pm 2.1$ & -- & $0.3 \pm 0.6$ & $1.3 \pm 1.5$ & $1.7 \pm 1.2$ \\
\hline Mean \pm S.D & $2.6 \pm 1.4$ & $3.3 \pm 1.5$ & $2.3 \pm 1.0$ & $2.6 \pm 1.5$ & $3.5 \pm 1.0$ & $2.7 \pm 1.7$ & $2.6 \pm 1.3$ & $3.3 \pm 1.5$ \\
\hline
\end{tabular}


Kassem, S. A. A.

Fig. (1): Natural abundance of the endoparasitoids $O$. pallipes and $C$. parksi in four tomato greenhouses . 
J. Agric. Sci. Mansoura Univ., 34 (11), November, 2009

Fig. (2): Percentage . of parasitism by the endoparasitoids 0 . pallips and $C$. parksi in four tomato greenhouses

10711 
In greenhouse (4), the percentage of parasitism by the endoparasitoids $O$. pallipes ranged $0.0-30.4 \%$ and recorded its peak on $20^{\text {th }}$ of April. On the other hand the percentages of parasitism by the endoparasitoid, C. parksi ranged $0.0-38.1 \%$ and recorded its peak on $13^{\text {th }}$ of April .

\section{DISCUSSION}

The larval pupal parasitoids, O. pallipes and C. parksi recorded two peaks of abundance in all tomato greenhouses during the current study. In previous investigations by Awadalla (1998), Awadalla et al (2003), Elkhouly( 2003) and El-khouly (2009) both parasitoids recorded three peaks of abundance on the summer crops and tomatoes in the open fields. The two peaks observed in the current study may be resulting from the short term of the growing season. On the other hand, the low abundance of $O$. pallipes and $C$. parksi may be explained by the high competition of the ectoparasitoid $D$. isaea. Another possible explanation is that both $O$. pallipes and C. parksi females cannot discriminate between unparasitized hosts and those previously attacked (Linden, 1986). Data suggested by El-Khouly (2003) concluded that correlation values between either $O$. pallipes and $C$. parksi and their host (L. trifolii) on broad bean and cowpea as host plants were lower than those of the ectoparasitoid $D$. isaea on the same host plants. The endoparasitoids $O$. pallipes and $C$. parksi prefer the low density of their insect hosts.

\section{REFERENCES}

Awadalla, S. S. (1998). Relationship between the serpentine leaf miner Liriomyza trifolii (Burgess) and its parasitoids on broad bean in Mansoura region. J. Agric. Sci. Mansoura Univ., 23(9):4019 - 4026

Awadalla, S. S.; L.M. Shanab; A. I. AbdEl-Kariem and A. R. El- Khouly (2003). Opius pallipes (Wesmeal) (Hymenoptera: Braconidae) as a larval pupal endoparasitoid on the serpentine leaf miner Liriomyza trifolii. First Egyptian and Syrian Conference. El. Minia University\&Al.Baath University on Agriculture \& Food in the Arab world, El-Minia: 8-11 December. 111-118

Ckman, E. and N. Uygun (2003). The deterrmination of leaf miners (Diptera: Agromyzidae ) and their parasitoids in the cultivated and non-cultivated areas in Sanlurfa province, Southern Turkey. Turk . Entomol. Dergisi, 27(4): 305-318

El-Khouly, A. R. (2003). Studies on some natural enemies associated with the serpentine leaf miner Liriomyza trifolii (Burgess). M.Sc. Thesis, Fac., Agric., Mansoura univ. $116 \mathrm{pp}$

El-Khouly, A. R. (2009). Efficiency of some hymenopterous parasitoids on serpentine leaf miner Liriomyza trifolii (Burgess). Ph.D. Thesis, Fac., Agric., Mansoura univ. 185 pp. 
Johnson, M. W.; E. R. Oatman and J. A. Wyman (1980). Natural control of Liriomyza sativa (Dip: Agromyzidae) in pole tomatoes in southern California . Entomophaga, 25 (2) : $193-198$

Linden, A. (1986). Ambition of exotic leaf miner parasites Chrysocharis parksi and Opius dimidiatus to the native Dutch parasite complex on tomato. Med. Fac. Land bouww. RijKs Univ. Gent., 51/3a, 1009-1015.

McClanhan, R. J. (1975). Notes on the vegetable leaf miner Liriomyza sativa (Diptera: Agromyzidae ) in Ontario. Proc. Entomol. Soc. Ont., 105: 40 44.

Parrella, M. P. (1984). Research on biological control of Liriomyza trifolii (Burgess) on Chrysanthemum with Chrysocharis parksi (Crowford). Dept. of Entomol., Univ. California, Riverside California, 92521, U.S.A. $9 \mathrm{pp}$.

Shahien, A. and M. M. A. El-Magraby (1993). Impact of the parasitoids of Liriomyza trifolii (Burgess) on broad bean. Zeilschrift Fur Angewand Zoologie, 79(1) : $37-43$

Zehnder, G.W. and J. T. Trumble (1984). Host selection of Liriomyza species (Diptera: Agromyzidae) and associated parasites in adjacent plantings of tomato celery. Environ. Entomol., 13: 492 - 496.

دور الطفيلين الـاخليين اويسيس بـاليبس و كرايزوكـاريس باركسـى فـى المكافحة الحيوية لحشرة نافقة أوراق الفول في الطفئ صوبات الطماطئ.

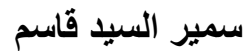

قسم بحوث" أفات الخضر - معهر بحوث وقاية النباتات- مركز البحوث الزراعية. محطة البحوث الزراعية بسخا.

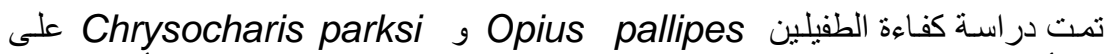

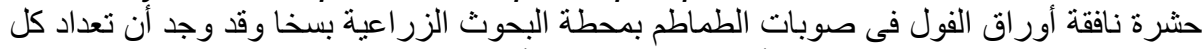

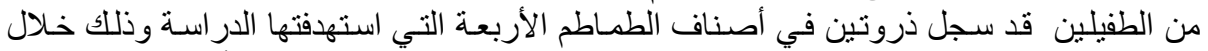

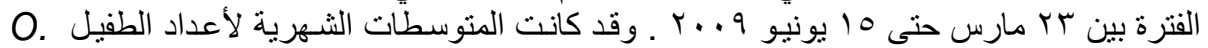

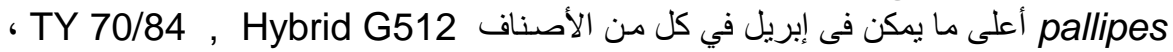

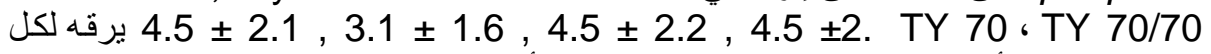

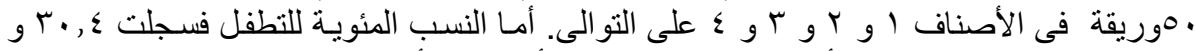
أ

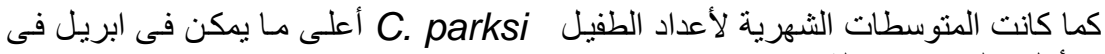

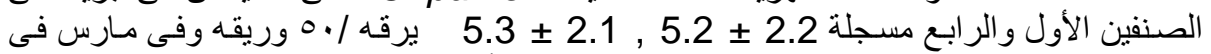

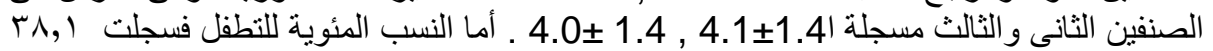
و r,

كلية الزراعه - جامعة المنصوره

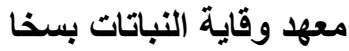

قام بتحكيم البحث

أ.د / أدمير البحث صالح ابراهيم عوض الله

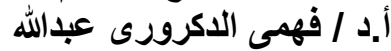

